\title{
Rafat Eatka
}

Kraków

\section{Problemy metodologiczne w prowadzeniu badań na temat historii Kościoła katolickiego w Polsce „ludowej”. Przegląd badań, postulaty badawcze}

Mierząc się z tematem historii Kościoła katolickiego w PRL, stoimy przed wieloma problemami natury metodologicznej. Można je zasadniczo podzielić na kilka grup, takich jak: dostępność źródeł i ich specyfika, trudność w uzyskaniu wiarygodnych relacji uczestników opisywanych wydarzeń, nośność społeczna tematyki czy wreszcie stosunek samego historyka do Kościoła. Nie są to oczywiście wszystkie problemy, przed jakimi staje badacz, analizując tę problematykę, ale z pewnością najbardziej istotne, więc na nich zasadniczo się skupię w swoim artykule. Opierając się na własnych doświadczeniach (badania dotyczące historii Kościoła i polityki władz wobec niego w latach osiemdziesiątych) i posiłkując się opracowaniami dotyczącymi zagadnień metodologiczno-źródłoznawczych, postaram się przedstawić najważniejsze utrudnienia, przed jakimi staje badacz tego okresu historii Kościoła ${ }^{1}$.

\section{Źródła archiwalne}

Cenne informacje na temat Kościoła w PRL możemy uzyskać przede wszystkim z dwóch rodzajów archiwów: państwowych i kościelnych (jako pewne uzupełnienie można traktować prywatne archiwa osób związanych z Kościołem, np. Jerzego Turowicza). Najważniejsze z pierwszej kategorii archiwaliów są dokumenty zgromadzone w zbiorach Archiwum Akt Nowych, w wojewódzkich oddziałach Archiwum Państwowego i w Instytucie Pamięci Narodowej (centrala, oddziały, delegatury) ${ }^{2}$.

\footnotetext{
Swoje rozważania oparłem na ustaleniach przedstawionych w świeżo opublikowanej pracy doktorskiej. Zob. szerzej: R. Łatka, Polityka władz PRL wobec Kościoła katolickiego w województwie krakowskim w latach 1980-1989, Kraków 2016.

${ }^{2}$ Zasób archiwalny Archiwum Instytutu Pamięci Narodowej zob., Informator o zasobie archiwalnym Instytutu Pamięci Narodowej (stan na dzień 31 grudnia 2008), red. J. Bednarek, R. Leśkiewicz, Warszawa 2009; Wartość naukowa i stan opracowania zasobu archiwalnego Instytutu Pamięci Narodowej, red. R. Kościański, R. Leśkiewicz, Poznań-Warszawa 2010. Por. F. Musiał, Stan badań nad dziejami komunistycznego aparatu represji za lata 2006-2010/2011, w: Archiwalia komunistycznego aparatu represji - zagadnienia źródłoznawcze, red. F. Musiał, Kraków 2012, s. 8-86; W. Suleja, Zasoby źródłowe Instytutu Pamięci Narodowej a badania nad najnowszymi dziejami Polski, w: ibidem, s. 87-96.
} 
Największe kontrowersje (jak udowodnię w dalszej części analizy, najczęściej niesłusznie) budzą dokumenty z zasobu IPN, gdzie znajduje się przede wszystkim dokumentacja wytworzona przez aparat represji Polski „ludowej”. Dzięki pracy wielu historyków zajmujących się badaniem historii PRL, znamy system funkcjonowania ${ }^{3}$, sposób ewidencjonowania akt ${ }^{4}$, struktury $^{5}$ i metody pracy operacyjnej aparatu bezpieczeństwa ${ }^{6}$. Co bardzo istotne dla badania historii Kościoła w tym okresie, znamy również sposób pracy operacyjnej i schematy walki $\mathrm{z}$ tą instytucją opracowane przez pracowników aparatu represji (co warto podkreślić, kierunek działania aparatu represji nadawała PPR, a następnie PZPR $)^{7}$.

W szeroko definiowanej sferze publicznej dominuje wyobrażenie, że wiarygodność dokumentacji dawnego aparatu represji jest bardzo niska, jest to jednak pogląd nieoparty na wiedzy na temat tej kategorii źródeł, lecz sąd o charakterze publicystycznym wyrażany najczęściej przez osoby niemające elementarnej wiedzy dotyczącej funkcjonowania aparatu represji. Wiarygodność akt tzw.,bezpieczniackich z wielu bowiem powodów jest wysoka. Świadczy o tym choćby przyjęty system pracy aparatu represji nastawiony na efektywność, kontrola pracy operacyjnej funkcjonariuszy UB/SB przez ich zwierzchników czy wreszcie konfrontacja wiadomości uzyskiwanych od osobowych źródeł informacji z innymi źródłami wiedzy operacyjnej ${ }^{8}$.

Trzeba w tym miejscu również powiedzieć, jakie materiały zgromadzone w IPN są najbardziej przydatne przy odtwarzaniu historii Kościoła katolickiego w PRL przede wszystkim w kontekście jego stosunków z władzami. Są to w pierwszej kolejności wytyczne formułowane przez wysokich rangą funkcjonariuszy aparatu UB/SB, a także MSW. Pozwalają nam one odtworzyć szeroko ujęte założenia polityki władz wobec Kościoła (i ich zbieżność z dyrektywami formułowanymi przez partię) ${ }^{9}$. Kolejnym niezwykle przydatnym typem dokumen-

${ }^{3}$ Np. H. Dominiczak, Organy Bezpieczeństwa PRL 1944-1990. Rozwój i dziatalność w świetle dokumentów MSW, Warszawa 1997; Aparat bezpieczeństwa w Polsce w latach 1954-1956. Taktyka, strategia, metody, wstęp A. Paczkowski, wybór i oprac. G. Majchrzak, A. Paczkowski, Warszawa 2011. Ciekawe jest porównanie funkcjonowania struktur aparatu bezpieczeństwa w poszczególnych państwach „bloku wschodniego”, zob. Czekiści. Organy bezpieczeństwa w europejskich państwach bloku sowieckiego 1944-1989, red. Ł. Kamiński, K. Persak, Warszawa 2010.

${ }^{4}$ Zob. J. Piłat, Zasady prowadzenia, funkcjonowanie oraz rola ewidencji operacyjnej SB z uwzględnieniem przydatności zachowanych materiatów ewidencyjnych $w$ bieżacej pracy Instytutu Pamięci Narodowej, w: W kręgu teczek. Z badań nad zasobem i funkcjami archiwum Instytutu Pamięci Narodowej, red. J. Bednarek, P. Perzyna, Łódź-Toruń 2006, s. 149-166.

${ }_{5}$ Aparat bezpieczeństwa w Polsce. Kadra kierownicza, t. I: 1944-1956, red. K. Szwagrzyk, Warszawa 2004; Aparat bezpieczeństwa w Polsce. Kadra kierownicza, t. II: 1956-1975, red. P. Piotrowski, Warszawa 2006; P. Piotrowski, Struktury Stużby Bezpieczeństwa MSW 1975-1990, „Pamięć i Sprawiedliwość" $2003 \mathrm{nr} 1$.

${ }^{6}$ Instrukcje pracy operacyjnej aparatu bezpieczeństwa 1945-1989, oprac. T. Ruzikowski, Warszawa 2004; F. Musiał, Podręcznik bezpieki: teoria pracy operacyjnej Stużby Bezpieczeństwa w świetle wydawnictw resortowych Ministerstwa Spraw Wewnętrznych PRL (1975-1989), Kraków 2007 (tam też literatura).

${ }^{7}$ Metody pracy operacyjnej aparatu bezpieczeństwa wobec Kościołów i związków wyznaniowych 1945-1989, red. A. Dziurok, Warszawa 2004; J. Żaryn, Kościót katolicki w PRL - wybrane zagadnienia, hipotezy, prowokacje, „Pamięć i Sprawiedliwość” 2005, nr 1, s. 26, 27.

${ }^{8}$ Wokót teczek bezpieki. Zagadnienia metodologiczno-źródłoznawcze, red. F. Musiał, Kraków 2008; F. Musiał, Wiarygodność dokumentacji operacyjnej UB/SB - wybrane zagadnienia źródłoznawcze, w: Archiwalia komunistycznego aparatu represji, s. 117-126.

${ }^{9}$ Najważniejsze dokumenty z tej kategorii zob. Metody pracy operacyjnej aparatu bezpieczeństwa wobec Kościolów. Por. z dokumentacją wytworzoną przez PZPR: Tajne dokumenty państwo-Kościót 1960-1980, Londyn 1996; Tajne dokumenty państwo-Kościót 1980-1989, Londyn-Warszawa 1993; 
tacji są wszelkiego rodzaju okresowe sprawozdania z działalności konkretnych wydziałów zajmujących się w ramach aparatu represji Kościołem. Pozwalają nam bowiem dostrzec skalę działań wymierzonych w tę instytucję i jej zmiany w różnym okresie trwania PRL. Wreszcie ostatnia z najbardziej przydatnych kategorii dokumentów, czyli materiały operacyjne $\mathrm{SB}^{10}$, na czele z najważniejszymi, ,Teczkami Ewidencji Operacyjnej na Księdza"11 i ich mutacjami dotyczącymi parafii: „Teczka Ewidencji Operacyjnej na Parafię”, i dotyczącymi biskupów, czyli „Teczka Ewidencji Operacyjnej na Biskupa" ". Bardzo istotne znaczenie mają również materiały pochodzące z teczek personalnych i osobowych tzw. ozi - czyli osobowych źródeł informacji $1^{13}$. Wszystkie wymienione wyżej kategorie akt aparatu represji dają nam możliwość uzyskania informacji, których nie uzyskalibyśmy z innych źródeł lub otrzymalibyśmy obraz jedynie częściowy (jak w przypadku relacji świadków).

Niemniej warto zauważyć, że ze względu na specyfikę tego typu dokumentacji przy prowadzeniu badań należy mieć świadomość, że obraz w nich przedstawiany jest spojrzeniem na rzeczywistość z punktu widzenia aparatu represji i nie oddaje całościowo opisywanego w nich zjawiska czy zagadnienia ${ }^{14}$. Tak więc patrząc $z$ drugiej strony, niezbędna dla poznania w pełni rzeczywistości Polski „ludowej” jest konfrontacja tej dokumentacji ze źródłami innej proweniencji ${ }^{15}$.

Niezwykle istotnym problemem, jaki pojawia się w prowadzeniu kwerendy akt aparatu represji Polski „ludowej”, jest niekompletność bazy archiwalnej, szczególnie jeśli chodzi o dokumentację dotyczącą Kościoła ${ }^{16}$, jej spore rozproszenie czy wreszcie trudność w poszu-

Wizyta Jana Pawła II w Polsce 1979. Dokumenty KC PZPR i MSW, oprac. A. Friszke, M. Zaremba, Warszawa 2005; A. Friszke, PRL wobec Kościoła. Akta 1970-1978, Warszawa 2010.

${ }^{10} \mathrm{Na}$ temat ich kategorii zob. F. Musiał, Podręcznik bezpieki.

${ }^{11}$ Teczka na księdza, „Karta” 1996, nr 20; D. Walusiak, TEOK. Teczka ewidencji operacyjnej na księ$d z a$, w: Kościót w godzinie próby 1945-1989. Nieznane dokumenty i świadectwa, Warszawa 2006, s. 288; R. Dyrycz, J. Laska, J. Raźny, E. Zając, Teczka ewidencji operacyjnej na księdza. Teoria i praktyka pracy operacyjnej SB, Kraków 2009.

${ }_{12}$ Zob. szerzej J. Marecki, Kwestionariusz personalny z Teczki Ewidencji Operacyjnej na Biskupa. Represje wobec Kościoła w krajach bloku wschodniego, w: Komuniści przeciw religii po 1944, red. J. Marecki, Kraków 2009, s. 131-141. Omówienie przykładowego TEOB: J. Urban, Teczka biskupa J. Pietraszki, w: Kościół katolicki w czasach komunistycznej dyktatury. Między bohaterstwem a agentura. Studia i materiały, t. I, Kraków 2007, s. 47-77. Przykładowy arkusz kronikarski TEOB: Bp Jan Pietraszko. Świadectwo świętości w aktach SB, w: Nigdy przeciw Bogu. Komunistyczna bezpieka wobec biskupów polskich, red. J. Marecki, F. Musiał, Warszawa-Kraków 2007, s. 332.

${ }^{13}$ Osobowe źródła informacji - zagadnienia metodologiczno-źródloznawcze, red. F. Musiał, Kraków 2008; Osobowe środki pracy operacyjnej. Zagadnienia źródłoznawcze, red. F. Musiał, Kraków 2013.

${ }^{14}$ F. Musiał, Zamiast wprowadzenia: archiwalia komunistycznego aparatu represji, w: Wokót teczek bezpieki, s. 60-62; W. Suleja, Złudny czar teczek, czyli teczkowe „grzechy główne”, w: Archiwalia komunistycznego aparatu represji, s. 111-116. Warto zwrócić również uwagę na specyfikę języka stosowanego przez funkcjonariuszy UB/SB: I. Dojka, Zakłamany słownik, czyli żargon funkcjonariuszy bezpieczeństwa PRL, Kraków 2011.

${ }^{15}$ Z. Zblewski, Kilka uwag o wykorzystywaniu zbiorów archiwalnych IPN w badaniach nad najnowszymi dziejami Polski, w: Archiwalia komunistycznego aparatu represji, s. 97-110.

${ }^{16}$ O brakowaniu dokumentów aparatu bezpieczeństwa i akt PZPR zob. S. Cenckiewicz, Znaczenie archiwaliów stużb specjalnych PRL w studiach nad dziejami „, Solidarności”, w: „Solidarność”. W imieniu narodu i obywateli, red. M. Latoszek, Kraków 2005, s. 237; T. Balbus, K. Stróżyna, Ojczyznę wolna racz nam wrócić Panie...” Komunistyczna bezpieka wobec kardynała Henryka Gulbinowicza w latach 1970-1990, Wrocław 2008, s. 133-151; R. Peterman, Proces brakowania i niszczenia akt organów bezpieczeństwa państwa w latach 1954-1990 na przykładzie województwa tódzkiego, w: Wokót teczek 
kiwaniu interesujących badacza materiałów ze względu na specyfikę archiwum IPN (choćby ze względu na brak dostępu przez badaczy do inwentarza i całościowych katalogów poszczególnych struktur aparatu bezpieczeństwa). Jak wynika z mojego doświadczenia badawczego i wiedzy powszechnej dla badaczy historii lat osiemdziesiątych w PRL, dokumentacja dotycząca tego okresu została gruntownie zdekompletowana. Brakuje zawartości teczek najważniejszych duchownych, osobowych źródeł informacji, a nawet sprawozdań z pracy Wydziału IV.

Analizę dokumentacji proweniencji partyjnej i administracji państwowej należy prowadzić $\mathrm{z}$ równie daleko posuniętą ostrożnością co przy aktach wytworzonych przez aparat represji. Mają one bowiem częściowo podobne wady co wspomniana wyżej dokumentacja. Przede wszystkim należy zwrócić uwagę na ich ideologiczne podłoże, specyficzny język i sporą liczbę pojawiających się w nich eufemizmów ${ }^{17}$. Innym istotnym faktem jest fasadowość wielu instytucji systemu Polski Ludowej i jej „teatralność”, ${ }^{18}$. Stąd należy zachować dystans przede wszystkim w stosunku do wystąpień publicznych najwyższych dygnitarzy Polski „ludowej” i oficjalnych dokumentów najważniejszych organów PZPR skierowanych do społeczeństwa. O wiele lepszym źródłem pod tym względem są protokoły narad poszczególnych organów partyjnych, przede wszystkim tych najważniejszych. Należy tu w wspomnieć przede wszystkim o Biurze Politycznym i Sekretariacie KC PZPR; jeśli zaś badamy historię Kościoła na terenie danego województwa, istotne będą protokoły posiedzeń KW PZPR czy Egzekutywy KW PZPR ${ }^{19}$.

Do najważniejszych dokumentów, jakie są przydatne w prowadzeniu badań na temat historii Kościoła, można zaliczyć wytworzone przez organy partyjne zajmujące się polityką wobec Kościoła (przede wszystkim Wydział Administracyjny KC PZPR i analogiczne wydziały w województwach) oraz dokumentacje Urzędu do spraw Wyznań i jego tereno-

bezpieki, s. 379-393; ,,Wojna o akta”. Studia i materiaty źródłowe, red. S. Flis, Gdańsk 2011; R. Drabik, Hasło „wycofywać”, czyli jak SB niszczyła akta w archiwach PZPR (1989), „Glaukopis” 2012, nr 25-26, s. 359-374; R. Kościański, Brakowanie i niszczenie dokumentów Wojewódzkiego Urzędu Spraw Wewnętrznych w Poznaniu w latach 1989-1990, w: Krok ku wolności. Wybory czerwcowe 1989 i ich konsekwencje, red. K. Białecki, S. Jankowiak, R. Reczek, Poznań 2015, s. 221-241.

${ }^{17}$ Choćby wystąpienie premiera Piotra Jaroszewicza z 1970 r., które pozwolę sobie tutaj zacytować: „Dążąc do umocnienia w ramach Frontu Jedności Narodu współdziałania wszystkich obywateli wierzących i niewierzących, zmierzać będziemy do pełnej normalizacji stosunków między państwem a Kościołem, oczekując zarazem, że wysiłki rządu spotkają się z właściwym zrozumieniem w duchownych i świeckich środowiskach". Mimo tej deklaracji władze wcale nie zaprzestały w latach siedemdziesiątych represji wymierzonych w Kościół, zob. na ten temat K. Pawlicka, Polityka władz wobec Kościoła katolickiego (grudzień 1970-październik 1978), Warszawa 2000; R. Gryz, Między liberalizacja a dezintegracją. Stosunki państwo-Kościót w latach siedemdziesiatych, w: Stosunki państwo-Kościót w Polsce w latach 1944-2010. Studia i materiały, red. R. Łatka, Kraków 2012, s. 73-92.

${ }^{18}$ Ciekawie pisze o tym R. Matyja, Państwowość PRL w polskiej refleksji politycznej lat 1956-1980, Kraków-Nowy Sącz 2007. Na temat funkcjonowania władzy w PRL zob. również Władza w PRL. Ludzie i mechanizmy, red. K. Rokicki, R. Spałek, Warszawa 2011; PZPR jako machina władzy, red. D. Stola, K. Persak, Warszawa 2012.

${ }^{19}$ Na temat roli KW PZPR i Egzekutywy KW PZPR zob. A. Boboli, Drugi po Komitecie Centralnym. Komitet Warszawski PZPR 1975-1989, w: Władza w PRL, s. 79-124; , Mikroświat”. Komitet Wojewódzki PZPR w Krakowie w latach 1956-1975, w: ibidem, s. 125-154. Zob. również P. Brzeziński, Zapomniani dygnitarze. Pierwsi sekretarze Komitetu Wojewódzkiego PPR/PZPR w Gdańsku w latach 1945-1990. Szkice biograficzne, Gdańsk 2013; M. Garyga, Dekada agonii: Komitet Krakowski PZPR w świetle materiałów partyjnych 1981-1990, Warszawa 2014; K. Zawadka, Komitet Wojewódzki PZPR w Lublinie 1948-1956. Struktura - ludzie - mechanizm funkcjonowania, Lublin 2014. 
wych wydziałów. Podobnie jak w przypadku dokumentacji aparatu bezpieczeństwa duża część zasobów archiwalnych UdsW i proweniencji partyjnej została zniszczona lub wybrakowana. Problem ten dotyczy szczególnie lat osiemdziesiątych. Z własnego doświadczenia mogę powiedzieć, że szczególnie mocno przetrzebione zostały dokumenty dotyczące Kościoła ze szczególnym uwzględnieniem skierowanych przeciwko niemu represji. Jak wynika z kwerendy, jaką przeprowadziłem w Archiwum Państwowym w Krakowie, w aktach miejscowego WdsW praktycznie nie ma żadnych informacji na temat prześladowania ludzi Kościoła. Dokumentacja dotycząca parafii i poszczególnych księży (każdy ksiądz miał swoją teczkę w odpowiednim WdsW) jest w dużej części zniszczona, a tę, która pozostała, staranie wybrakowano ${ }^{20}$. Większość z tych dokumentów została zniszczona lub sprywatyzowana w latach 1989-1990, jak wynika z wiedzy archiwistów AP w Krakowie ${ }^{21}$.

Ze źródłami kościelnymi dotyczącymi historii Kościoła katolickiego w PRL jest inny problem niż w przypadku dokumentacji partyjnej czy aparatu represji. Mówiąc ściśle, wiąże się on $\mathrm{z}$ mocno ograniczoną dostępnością owych akt ${ }^{22}$. Instytucje kościelne $\mathrm{z}$ wielu powodów nie chcą udostępniać swoich zbiorów badaczom historii Polski „ludowej”. Najistotniejszą w moim przekonaniu przyczyną takiej decyzji władz kościelnych jest czysto psychologiczna chęć chronienia Kościoła przed atakami jego krytyków i obawa, że dokumentacja kościelna zostanie użyta przeciwko tej instytucji. Tego typu „ostrożność” archiwistów tej instytucji jest dość daleko posunięta i nie są udostępniane nawet akta przebiegu służby duchownej poszczególnych księży (chronione pięćdziesięcioletnią klauzulą). Mogę w tym miejscu wspomnieć o słowach, jakie usłyszałem w archiwum krakowskiej kurii, gdy zapytałem, czy są dostępne kościelne dokumenty dotyczące wizyt Jana Pawła II w Krakowie. Siostra zajmująca się na co dzień archiwum w odpowiedzi stwierdziła, że najpierw temat musi zostać opracowany przez historyków kościelnych. Jedyne, co mogłem otrzymać, to katalogi duchowieństwa krakowskiego zawierające jedynie podstawowe informacje na temat księży (wydawane w sposób nieregularny) ${ }^{23}$. Podobne doświadczenia, jeśli chodzi o podejście archiwistów kościelnych, mają również inni historycy dziejów najnowszych. Mogę w tym miejscu wymienić choćby Antoniego Dudka czy Filipa Musiała, którzy w swojej działalności naukowej również zajmowali się tego typu tematyką.

Niemniej jednak w ostatnich latach trend ten zaczyna się nieco zmieniać. Niektórzy historycy otrzymali bowiem dostęp do części dokumentacji zgromadzonej w najważniejszych kościelnych archiwach, przede wszystkim w Archiwum Sekretariatu Episkopatu Polski czy też w Archiwum Prymasa Polski ${ }^{24}$. Warto jednak podkreślić, iż dostęp do wspomnianych ma-

\footnotetext{
${ }^{20}$ Mogę podać jako przykład teczkę księdza Jana Gwizdonia, APK 29/1431/28, Akta osobowe J. Gwizdoń, czy akta dotyczące parafii, w których nie ma śladu żadnych represji wobec duchownych, którzy w niej pracowali, APK 29/1431/187WdsW, Akta parafii Dobrego Pasterza Prokocim Czerwony, Kraków-Śródmieście, gdzie większość akt dotyczy kwestii budowlanych i renowacji zabytków kościoła.

${ }^{21}$ Relacja ks. prof. J. Mareckiego z 2011 r., któremu z kolei tę wiedzę przekazali archiwiści AP w Krakowie.

${ }^{22}$ Komunizm i religia w Polsce - trwanie i zmiana, „Pamięć i Sprawiedliwość” 2005, nr 1, s. 36.

${ }^{23}$ Co istotne, sytuacja wygląda różnie w poszczególnych diecezjach. Przykładowo w Archiwum Diecezjalnym w Płocku czy Siedlcach dokumenty dotyczące kontaktów z władzami są udostępniane badaczom, Relacja A. Dudka z marca 2012 i relacja ks. prof. Władysława Góralskiego z maja 2012. Por. B. Kaliski, Archidiecezja gnieźnieńska w czasach komunizmu 1945-1980, Warszawa 2012, s. $16,17$.

${ }^{24} \mathrm{Na}$ ten temat zob. J. Żaryn, Kościót katolicki w PRL - wybrane zagadnienia, hipotezy, prowokacje, s. 16, 17; M. Smoliński, Biskup negocjator. Zygmunt Choromański (1892-1968), Warszawa 2014, s. 18-20.
} 
teriałów otrzymują przede wszystkim historycy blisko związani z Kościołem. Pozostaje mieć nadzieję, że nastąpi dalszy postęp pod tym względem i dokumentacja kościelna z biegiem lat zostanie udostępniona wszystkim zainteresowanym nią badaczom ${ }^{25}$.

\section{Relacje świadków}

Jak zawsze w przypadku relacji uczestników wydarzeń badacz musi zachować daleko posuniętą ostrożność. Łatwo bowiem ulec „urokowi” świadków epoki, do których odczuwa się głęboki szacunek bądź — z drugiej strony — negatywny stosunek również potrafi w znacznym stopniu wypaczyć osąd badacza. Niezbędna jest więc troska o to, by świadków traktować w sposób możliwie maksymalnie neutralny.

Jeśli chodzi o badanie historii Kościoła w Polsce „ludowej”, do najważniejszych świadków należą metropolici, biskupi i księża odpowiadający za kontakty z władzami zarówno oficjalne, jak i nieoficjalne (w dalszej kolejności proboszczowie, którzy z racji sprawowanej funkcji mieli najczęściej do czynienia z urzędnikami UdsW czy pracownikami aparatu bezpieczeństwa), funkcjonariusze aparatu represji czy wysocy rangą urzędnicy UdsW. Uzyskanie rzetelnych relacji od osób z tych dwóch kategorii nie jest łatwe. O ile chodzi o ludzi Kościoła, nie brakuję księży, którzy chętnie podejmą temat historii tej instytucji ${ }^{26}$. Jednak z reguły im wyższa sprawowana funkcja, tym zwykle kontakt jest trudniejszy (choć oczywiście są od tej zasady wyjątki). Niestety, niedawno rozmowy na temat polityki władz wobec Kościoła w latach osiemdziesiątych odmówił mi kard. Franciszek Macharski. Podobnie jak w przypadku archiwistów kościelnych wydaje się, że głównym powodem jest obawa, że ich słowa mogą zostać wykorzystane w sposób sprzeczny z interesem Kościoła.

Niemniej nie brakuje jednak wielu opublikowanych relacji części z najważniejszych ludzi Kościoła w omawianym okresie. Do najbardziej istotnych można zaliczyć fragmenty dziennika prymasa Wyszyńskiego z różnych okresów jego życia ${ }^{27}$, relacje prymasa Józefa Glempa $^{28}$, zapiski wieloletniego sekretarza Episkopatu Polski Bronisława Dąbrowskiego ${ }^{29}$ czy książkę Alojzego Orszulika ${ }^{30}$. Nie brakuje też wspomnień poszczególnych szeregowych księży, szczególnie z lat osiemdziesiątych ${ }^{31}$.

W przypadku świadków związanych z aparatem bezpieczeństwa i UdsW sytuacja jest w znacznej mierze odmienna i powody niechęci do dzielenia się z badaczem posiadaną wie-

\footnotetext{
${ }^{25}$ Wydaje się, że władze kościelne zmierzają w tym kierunku. Świadczy o tym m.in. rozpoczęcie prac nad opracowaniem dzienników prymasa Stefana Wyszyńskiego, które mają ogromną wartość źródłową dla wszystkich badaczy zajmujących się dziejami Kościoła katolickiego w PRL.

${ }^{26}$ By wspomnieć choćby ks. Tadeusza Isakowicza-Zaleskiego czy ks. Stanisława Małkowskiego.

${ }^{27}$ S. Wyszyński, Zapiski więzienne, Warszawa 1995; idem, Zapiski milenijne. Wybór z dziennika „Pro memoria" z lat 1965-1967, Warszawa 2001; idem, Pro memoria. Zapiski z 1948-1949 i 1953-1954, Warszawa 2007; 1978: wybór papieża Jana Pawła II: zapiski prymasa, oprac. P. Raina, Warszawa 2008. Zob. także Człowiek niezwykłej miary. Ojciec Święty Jan Pawet II o kardynale Wyszyńskim. Kardynat Stefan Wyszyński o sobie. Kardynat Józef Glemp o kardynale Wyszyńskim, Warszawa 1984; P. Raina, Prymas Wyszyński i Solidarność, Warszawa 2005.

28 J. Glemp, Piętnaście lat postugi prymasowskiej, Warszawa 1997.

${ }^{29}$ P. Raina, Stan wojenny w zapiskach arcybiskupa Dąbrowskiego, Warszawa 2006.

${ }^{30}$ A. Orszulik, Czas przełomu, notatki ks. Alojzego Orszulika z rozmów z władzami PRL 1981-1989, Warszawa-Ząbki 2006.

${ }^{31}$ Choćby ks. Stefana Miecznikowskiego: Kazania stanu wojennego, Łódź 1992; ks. Józefa Gorzelanego: Gdy nadszedt czas budowy Arki: dzieje budowy kościoła w Nowej Hucie, Paryż 1998; czy ks. Tadeusza Isakowicza-Zaleskiego, Moje życie nielegalne, Kraków 2012.
} 
dzą są inne ${ }^{32}$. Na pierwszy plan wysuwa się groźba penalizacji czynów, które nawet z punktu widzenia peerelowskiego prawa były przestępstwami ${ }^{33}$. Drugą sprawą jest dążenie do chronienia swoich mocodawców i niechęć do rozmowy o szczegółach pracy operacyjnej w konkretnych sprawach. Jak wynika z doświadczeń Filipa Musiała o ile esbecy są skłonni mówić ogólnie o metodach i wytycznych, o tyle nie chcą nic powiedzieć na temat konkretnych przypadków swojego działania. Mimo to traktują swoją pracę w aparacie represji jako zwykłe zajęcie i nie mają sobie nic do zarzucenia ${ }^{34}$.

\section{Źródla publikowane, monografie i opracowania}

Istotnym ułatwieniem dla badaczy historii polskiego Kościoła z lat 1944-1989 jest dość duża liczba publikacji dotyczących tej materii ${ }^{35}$. Nie brakuje edycji źródłowych dokumentów partyjnych, organów przeznaczonych do walki z Kościołem czy wreszcie samej dokumentacji kościelnej, w tym przede wszystkim Episkopatu ${ }^{36}$. Powstało również wiele opracowań, poczynając od syntez $^{37}$, przez monografie związane $z$ różnymi okresami historii Kościoła w PRL ${ }^{38}$, prace dotyczące działalności zakonów ${ }^{39}$, regulacji stosunków prawnych między państwem i Kościołem ${ }^{40}$ czy

${ }^{32}$ Do wyjątków należą wspomnienia byłego kierownika UdsW Kazimierza Kąkola: Spowiedź pogromcy Kościoła, Olsztyn 1994; oraz Kazimierza Barcikowskiego: U szczytów władzy, Warszawa 1998.

${ }^{33}$ By wymienić w tym miejscu choćby działalność tzw. Grupy „D” MSW. Zob. szerzej M. Lasota, O raporcie sejmowej komisji poświęconej Samodzielnej Grupie „D” w MSW, „Biuletyn IPN” 2003, $\mathrm{nr}$ 1, s. 37-56; idem, Informacja o działalności komórek „D” pionu IV bylej Stużby Bezpieczeństwa, ibidem, s. 29-36.

${ }^{34}$ Relacja funkcjonariusza SB Marka Soczówki (udostępniona dzięki uprzejmości M. Gawlikowskiego); relacja funkcjonariusza SB Ryszarda Palczykowskiego (udostępniona dzięki uprzejmości M. Gawlikowskiego).

${ }^{35}$ Wynika to, jak trafnie zauważył Jan Żaryn, z ogromnej rozległości tematu. Zob. szerzej idem, Kościót katolicki w PRL — wybrane zagadnienia, hipotezy, prowokacje, s. 11.

${ }^{36}$ Listy pasterskie Episkopatu Polski 1945-2000, cz. I-II, Marki 2003; Komunikaty Konferencji Episkopatu Polski, oprac. J. Żaryn, Warszawa 2006.

${ }^{37}$ J. Żaryn Dzieje Kościoła katolickiego w Polsce (1944-1989), Warszawa 2003; A. Dudek, R. Gryz, Komuniści i Kościót w Polsce (1945-1989), Kraków 2006; Z. Zieliński, S. Bober, Kościół w Polsce 1944-2007, Poznań 2009; Stosunki państwo-Kościót w Polsce w latach 1944-2010.

${ }^{38} \mathrm{~Np}$. K. Pawlicka, Polityka władz wobec Kościola; Ł. Marek, „, Kler to nasz wróg”: polityka władz państwowych wobec Kościoła katolickiego na terenie województwa katowickiego w latach 1956-1970, Katowice 2009.

${ }^{39}$ D. Zamiatała, Zakony męskie w Polityce władz komunistycznych $w$ Polsce $w$ latach 1945-1989, t. I: Problematyka organizacyjno-personalna, Kielce 2009; t. II: Działalność duszpasterska i społeczna zakonów w latach 1945-1989, Warszawa 2012.

${ }^{40}$ B. Fidelus, Sytuacja prawna Kościoła katolickiego w Polsce, „Tygodnik Powszechny” 1989, nr 26; A. Stelmachowski, Regulacja stosunków prawnych między Państwem a Kościotem w latach 1980-1989, Szczecin 2000; Prawo i polityka wyznaniowa w Polsce Ludowej. Materiaty z II Ogólnopolskiego Sympozjum Prawa Wyznaniowego (Kazimierz Dolny, 26-28 października 2004), red. A. Mezglewski, P. Stanisz, M. Ordon, Lublin 2005. Od kilku lat funkcjonuje aktywnie Polskie Towarzystwo Prawa Wyznaniowego, które wydaje wartościowe prace na temat prawnych uregulowań stosunków państwo-Kościół w Polsce „ludowej”. Wśród wydanych prac szczególnie warte uwagi są: A. Szymański, Proces likwidacji działalności charytatywnej Kościoła katolickiego $w$ sferze publicznoprawnej w latach 1944-1965. Studium historyczno-prawne, Opole 2010; A. Mezglewski, H. Misztal, P. Stanisz, Prawo wyznaniowe, Warszawa 2011; D. Walencik, Nieruchomości Kościoła katolickiego w Polsce w latach 1918-2012. Regulacje prawne, nacjonalizacja, rewindykacja, Katowice 2013; Kościoły $i$ inne zwiąki wyznaniowe w stużbie dobra wspólnego, 
środowisk katolików świeckich ${ }^{41}$, a kończąc na biografiach ${ }^{42}$. Istotne z punktu widzenia badawczego są też publikacje dotyczące działań aparatu represji wobec tej instytucji i jej najważniejszych przedstawicieli, których pojawiło się naprawdę wiele ${ }^{43}$. Relatywnie najsłabiej ze względu na mocne wybrakowanie dokumentacji opisane są lata osiemdziesiąte ${ }^{44}$. Z innych prac poświęconych historii Kościoła w Polsce „ludowej” warto szczególnie zwrócić uwagę na trzy wydawane w Krakowie serie: Niezłomni ${ }^{45}$, Kościół katolicki w czasach komunistycznej dyktatury. Między bohaterstwem a agentura. Studia i materiaty ${ }^{46}$, Kościót w okowach ${ }^{47}$.

W ostatnich latach powstaje coraz więcej prac dotyczących historii Kościoła w Polsce „ludowej” w poszczególnych regionach kraju ${ }^{48}$ oraz opracowań poświęconych niezagospodaro-

red. W. Uruszczak, K. Krzysztofek, M. Mikuła, Kraków 2014. Warto wspomnieć również o periodyku naukowym Towarzystwa, które wychodzi pod nazwą „Przegląd Prawa Wyznaniowego” (dotychczas ukazało się siedem tomów).

${ }^{41}$ A. Micewski, Wspótrzadzić czy nie kłamać? PAX i Znak w Polsce 1945-1976, Paryż 1978; A. Friszke, Oaza na Kopernika: Klub Inteligencji Katolickiej 1956-1989, Warszawa 1997; idem, Koło posłów „Znak” w Sejmie 1957-1976, Warszawa 2002; C. Kuta, „Działacze” i „pismaki”: aparat bezpieczeństwa wobec organizacji katolików świeckich w Krakowie, Kraków 2009; R. Graczyk, Cena przetrwania? SB a Tygodnik Powszechny, Warszawa 2011; Sensus catholicus. Katolicy świeccy w Polsce Ludowej. Postawy - aktywność - myśl, red. R. Ptaszyński, T. Sikorski, Toruń 2014 (tam też wykaz najnowszej literatury dotyczącej tej problematyki).

${ }^{42}$ Pełny stan literatury zestawiłem w swojej rozprawie doktorskiej: R. Łatka, Polityka władz Polskiej Rzeczpospolitej Ludowej wobec Kościoła katolickiego w województwie krakowskim w latach 1980 1989, praca doktorska obroniona w 2014 r. w INPiSM UJ. Por. z zestawieniem dorobku ośrodków kościelnych zajmujących się badaniem dziejów Kościoła w ostatnim dziesięcioleciu: „Kościół w Polsce. Dzieje i kultura” 2015, t. XIV, s. 7-245, 323-374.

${ }^{43}$ Ku prawdzie i wolności. Komunistyczna bezpieka wobec kard. Karola Wojtyty, red. J. Marecki, F. Musiał, Kraków 2009; T. Balbus, K. Stróżyna, „Ojczyznę wolna racz nam wrócić Panie...”; Nigdy przeciw Bogu; W obronie Ojczyzny i Kościoła. Komunistyczna bezpieka wobec biskupów polskich, red. J. Marecki, F. Musiał, Kraków 2008; Niezłomni, w obronie ojczyzny i Kościoła. Komunistyczna bezpieka wobec biskupów polskich, Kraków 2008; W stużbie Boga i Polski. Komunistyczna bezpieka wobec kardynała Stefana Wyszyńskiego, oprac. J. Marecki, P. Nitecki, R. Szczypta-Szczęch, Kraków 2014.

44 R. Łatka, Polityka władz Polskiej Rzeczypospolitej Ludowej.

${ }^{45}$ Wymienione już wcześniej: Ku prawdzie $i$ wolności; Nigdy przeciw Bogu; Niezłomni, w obronie ojczyzny i Kościoła; W stużbie Boga i Polski.

${ }^{46}$ T. I pod red. R. Terleckiego i J. Szczepaniaka, Kraków 2007; t. II pod red. R. Terleckiego i J. Szczepaniaka, Kraków 2008; t. III pod red. J. Szczepaniaka i M. Lasoty, Kraków 2010.

${ }^{47}$ W ramach serii Kościół w okowach wydawanej przez krakowski Oddział Instytutu Pamięci Narodowej opublikowano wartościowe prace poświęcone dziejom Kościoła: t. I: P. Mardyła, Duszpasterstwo w czasach stalinowskich. Władze komunistyczne wobec działalność duszpasterskiej Kościoła rzymskokatolickiego w archidiecezji krakowskiej w latach 1945-1956, Kraków 2009; t. II: Represje wobec Kościoła w krajach bloku wschodniego. Komuniści przeciw religii po 1944 r., Kraków 2011; t. III: Niezłomni ludzie Kościoła. Sylwetki, red. J. Żaryn, Kraków2011; t. IV: Aparat represji wobec Kościoła w latach 1944-1956. Terytorium obecnej diecezji sandomierskiej, red. M. Krzysztofiński, J. Marecki, B. Stanaszek, Kraków 2012; t. VI: Represje wobec osób duchownych i zakonnych na terenie woj. krakowskiego 1944-1975. Leksykon biograficzny, t. I, red. J. Marecki, Kraków 2014; t. VII: Duszpasterstwa środowiskowe Archidiecezji Krakowskiej w latach 1945-1989, red. C. Kuta, J. Marecki, Kraków 2015; t. VIII: Komunistyczny aparat represji wobec Polskiej Prowincji Dominikanów, red. M. Mławicki, M. Wenklar, Kraków 2015; R. Łatka, Polityka władz PRL wobec Kościoła katolickiego w województwie krakowskim w latach 1980-1989, Kraków 2015.

${ }^{48}$ Wspomnieć należy przede wszystkim o: A. Kopiczko, Kościót warmiński a polityka wyznaniowa władz po II wojnie światowej, Olsztyn 1996; Kościót katolicki na Dolnym Ślasku w powojennym 50-leciu, 
wanym wcześniej obszarom badawczym — m.in. o pielgrzymkach Jana Pawła II do Ojczyzny w okresie PRL ${ }^{49}$. Istnieją jednak ciągle tematy szerzej niepodejmowane przez historyków dziejów najnowszych. Przykładowo do chwili obecnej nie powstała jeszcze całościowa monografia dotycząca Urzędu ds. Wyznań. Na temat działalności tej struktury aparatu wyznaniowego powstało raptem kilka prac ${ }^{50}$. Podobny brak istnieje w opisie ograniczeń w budownictwie sakralnym będącym w okresie Polski „ludowej” jednym z najważniejszych środków nacisku władz na Kościół. Do chwili obecnej nie powstała całościowa monografia dotycząca tej problematyki ${ }^{51}$.

red. I. Diec, K. Matwijowski, Wrocław 1996; J. Myszor, Historia diecezji katowickiej, Katowice1999; M. Mikołajczyk, Władza ludowa a diecezja częstochowska, Częstochowa 2000; idem, Problemy religijno-moralno-spoteczne diecezji częstochowskiej w latach 1945-1989 wynikające z ówczesnej sytuacji politycznej, Częstochowa 2002; K. Grzesiak, Relacje państwo-Kościót katolicki na terenie diecezji wroctawskiej w latach 1945-1989, Torun 2009; Kościót katolicki w realiach władzy komunistycznej na Pomorzu Środkowym w latach 1945-1989, red. T. Ceynowa, P. Knap, Szczecin 2011; B. Kaliski, Archidiecezja gnieźnieńska w czasach komunizmu; R. Łatka, Polityka władz Polskiej Rzeczypospolitej Ludowej. Warto wspomnieć ponadto o dwóch cennych seriach wydawanych przez poznański oddział IPN: Władze wobec Kościołów i związków wyznaniowych w Wielkopolsce: t. I-IV, red. K. Białecki, Poznan 2008-2011, oraz: Władze wobec Kościołów i związów wyznaniowych na Środkowym Nadodrzu: t. I-III, red. E. Wojcieszyk, Poznań 2012-2014.

49 Wizyta Jana Pawta II w Polsce 1979. Dokumenty KC PZPR i MSW; Jan Pawet II w Szczecinie. Meldunki operacyjne Wojewódzkiego Urzędu Spraw Wewnętrznych z 1987 r., oprac. M. Semczyszyn, A. Sitkowska, Z. Stanuch, Warszawa-Szczecin 2008; Operacja Zorza II. Stużba Bezpieczeństwa i Komitet Wojewódzki PZPR wobec wizyty Jana Pawła II w Trójmieście, red. S. Cenckiewicz, M. Kruk, WarszawaGdańsk 2008; Brama do wolności. Trzecia pielgrzymka Jana Pawła II do Polski, red. Z. Struzik, P. Skibiński, Warszawa 2012; R. Łatka, Propaganda władz PRL wobec II wizyty Jana Pawła II na przyktadzie Gazety Krakowskiej, „Komunizm. System - Ludzie - Dokumentacja” 2013, nr 2, s. 95-107; idem, Stosunki państwo-Kościół w latach osiemdziesiatych na przykładzie wizyt Jana Pawła II w Krakowie, w: Stosunki państwo-Kościót w Polsce w latach 1944-2010, s. 93-104; idem, SB wobec III pielgrzymki Jana Pawta II do PRL na przyktadzie Krakowa, „Glaukopis” 2014, nr 31, s. 349-368; idem, Stużba Bezpieczeństwa wobec drugiej wizyty Jana Pawła II w PRL w 1983 roku na przykładzie Krakowa, w: II Zimowa Szkoła Historii Najnowszej. Referaty, red. Ł. Kamiński, T. Sudoł, M. Żuczkowski, Warszawa 2014, s. 213-220; Pielgrzymki Jana Pawła II do Krakowa w oczach SB. Wybór dokumentów, oprac. R. Łatka, Kraków 2013; Pielgrzymka nadziei. II Wizyta Jana Pawła II w Ojczyźnie, Warszawa 2014.

${ }^{50}$ Najważniejsza $\mathrm{z}$ nich to opracowanie poświęcone funkcjonowaniu rzeszowskiej struktury UdsW: L. Fidjasz, Stosowanie prawa przez Wydziat do spraw Wyznań w Rzeszowie wobec duchownych Kościoła katolickiego w latach 1950-1973, Lublin 2012. Wśród innych prac warto wspomnieć o: H. Misztal, A. Mezglewski, Zarys kompetencji, styl dziatania i cele Urzędu ds. Wyznań, w: Prawo i polityka wyznaniowa w Polsce Ludowej, s. 33-70. Por. A. Nowakowski, Administracja spraw wyznaniowych w powojennej Polsce, „Kościół i Prawo” 1998, t. XIII, s. 27-39; R. Szczęch, Między jawnym a tajnym. Wspótpraca pionów wyznaniowych administracji państwowej i aparatu bezpieczeństwa na terenie Polski poludniowej w celu uskutecznienia działań przeciwko duchowieństwu w latach 40 i 50 XX wieku, w: Kościół katolicki w czasach komunistycznej dyktatury, t. III, s. 119-140.

${ }^{51}$ Dysponujemy jedynie opracowaniami omawiającymi te kwestie w odniesieniu do pewnych okresów w historii relacji państwowo-kościelnych. Do najważniejszych pod tym względem publikacji należą: A. Dudek, Lawirowanie. Ekipa Gierka wobec Kościoła katolickiego (1971-1978), „Więź” 1997, nr 7, s. 125-152; idem, Problem budownictwa sakralnego w stosunkach państwa z Kościołem rzymskokatolickim w Polsce w latach 1957-1970, „Dzieje Najnowsze” 1995, nr 1, s. 31-46; R. Gryz, Pozwolić czy nie? Władze PRL wobec budownictwa katolickich obiektów sakralnych w latach 1971-1980, Kielce 2007; idem, Między liberalizacja a dezintegracja, s. 73-92. Powstało również niewiele monografii dotyczących wspomnianej tematyki w odniesieniu do poszczególnych diecezji. Warto wspomnieć przede wszystkim o następujących: W. Skworc, Budownictwo kościołów w diecezji katowickiej w latach 1945-1989, Katowice 1996; A. Szypuła, Historia nowych kościołów w diecezji przemyskiej 1966-1993, t. I-IV, Rzeszów 1997-1998. 
Ogromna liczba publikacji dotycząca historii Kościoła w PRL znacząco ułatwia pracę badawczą i pozwala na konfrontacje ustaleń innych autorów z wiedzą, którą udało się uzyskać, badając nowe źródła lub przyjmując odmienną perspektywę przy analizie wykorzystywanej już wcześniej dokumentacji. Niemniej konieczne jest, zanim zasiądzie się do pracy, dokładne rozpoznanie literatury, tak by nie powtarzać ustaleń innych badaczy, co niestety zdarza się dość często, szczególnie u początkujących autorów.

\section{Badacz i jego ograniczenia}

W ostatnich dwudziestu-trzydziestu latach nastąpił istotny zwrot, jeśli chodzi o poznanie historyczne, jego możliwości i granice. Czymś oczywistym stało się, że nie ma czegoś takiego jak poznanie neutralne aksjologicznie. Każdy badacz jest bowiem w określony sposób uwarunkowany przez miejsce i kulturę, w których żyje, a jego podejście do przedmiotu badania jest $\mathrm{z}$ tego powodu $\mathrm{w}$ różnym zakresie skażone subiektywizmem ${ }^{52}$. Istotną różnicą między dobrym a złym historykiem jest świadomość własnych ograniczeń i niepewności co do własnych ustaleń badawczych. Musi on z natury rzeczy poruszać się między „dwoma wykluczającymi się wymogami: tworzenia prawdziwych wypowiedzi oraz deklarowania i respektowania względności tych wypowiedzi",53. Pamięć o tym ograniczeniu pozwala wyciągać ostrożne wnioski oparte na materiale źródłowym i logicznym rozumowaniu, nie zaś na osobistych poglądach badacza na daną kwestię. Należy, jak formułowali to już Tukidydes i Polibiusz, prezentować fakty, a nie przedstawiać efektowne opisy ${ }^{54}$.

Trzeba z pewnością zadbać również o dystans do opisywanego przedmiotu badań. Jest to szczególnie istotne w przypadku historyków silnie związanych z Kościołem. Przykładem niech będzie ocena prymasa Wyszyńskiego. Można bowiem bez większej przesady stwierdzić, że opis jego działalności jako przywódcy polskiego Kościoła został w istotny sposób zmitologizowany - w przypadku bardzo wielu poświęconych mu prac można mówić nawet o hagiografii (problem ten dotyczy głównie badaczy kościelnych, choć oczywiście nie tylko ich) $)^{55}$. Szczególnie powinien pamiętać o tym historyk, zajmując się tak nośnym społecznie tematem jak historia Kościoła w Polsce „ludowej”. Badacz nie może sobie pozwolić na stawianie tez uwarunkowanych jego stosunkiem do religii i związku wyznaniowego, którego jest członkiem; nie może też być nastawiony zanadto krytycznie do obiektu swoich badań. Stosunek historyka do religii był obiektem rozważań wielu badaczy już od najdawniejszych czasów, a tezy sformułowane przez choćby Arnolda Toynbee'go nie straciły na aktualności ${ }^{56}$.

\section{Podsumowanie}

Jak widać z przedstawionej przeze mnie wyżej argumentacji, historyk, badając dzieje Kościoła katolickiego w „Polsce Ludowej”, stoi przed wieloma zróżnicowanymi problemami i zagadnieniami o charakterze metodologicznym, na które musi bacznie zwracać uwagę.

\footnotetext{
${ }^{52}$ Ciekawym studium na ten temat jest: W. Wrzosek, O myśleniu historycznym, Bydgoszcz 2009.

${ }^{53}$ R. Koselleck, Semantyka historyczna, przeł. W. Kunicki, oprac. H. Orłowski, Poznań 2001, s. 194. Por. W. Zajewski, Czy historycy pisza prawdę, Kraków 2015, s. 13-26.

${ }^{54}$ P. Kimla, Historycy-politycy jako źródto realizmu politycznego, Kraków 2009, s. 62.

${ }_{55} \mathrm{Na}$ takie ryzyko zwracał szczególnie wyraźnie uwagę Zygmunt Zieliński, jeden z najwybitniejszych badaczy dziejów polskiego Kościoła w XX w., idem, Przedmowa do: Prymas Tysiąclecia w komunistycznym państwie, red. idem, Radom 2003, s. 5.

${ }^{56}$ A. Toynbee, Stosunek historyka do religii, Kęty 2007.
} 
Z pewnością najważniejsze wśród nich są problemy ze źródłami archiwalnymi, ich rozproszeniem, wybrakowaniem, jak i ich specyfiką. Istotne są również zagadnienia związane ze świadkami wydarzeń, przede wszystkim trudność w uzyskaniu wiarygodnych relacji od ich bezpośrednich uczestników, co szczególnie powinno skłaniać badacza do ostrożnego wyciągania wniosków z relacji, które uzyskał. Na koniec warto wspomnieć o ograniczeniach samego badacza, które wynikają z jego stosunku do podjętego tematu badań. Przede wszystkim mam tu na myśli stosunek do religii i instytucji, której jako wierny jest członkiem. Nie może on mu przesłaniać celu, do jakiego dąży, czyli rzetelnego opisu. Wszystkie wskazane wyżej problemy metodologiczne mają zasadniczy wpływ na ostateczną konstrukcję przygotowywanej publikacji i jej jakość. Brak znajomości ograniczeń źródeł, z których się korzysta, może doprowadzić do napisania słabej pracy, która nie będzie miała żadnej wartości naukowej. 